\title{
Micro-crack Formation in Direct Methanol Fuel Cell Electrodes
}

\author{
Qing $\mathrm{Li}^{\dagger}$, Dusan Spernjak, Piotr Zelenay, and Yu Seung Kim \\ Materials Synthesis and Integrated Devises Group, Los Alamos National Laboratory, \\ Los Alamos, New Mexico 87545, USA
}

${ }^{\dagger}$ Current address: Department of Chemistry, Brown University, Providence, Rhode Island, 02912, USA

*Corresponding author; phone: +1-505-667-5782; fax: +1-505-665-4292; e-mail: yskim@1anl.gov 


\begin{abstract}
:
This study focuses on the micro-crack formation of Nafion ${ }^{\circledR}$-based membrane electrode assemblies (MEAs) after extended direct methanol fuel cell (DMFC) operation. All electrodes, both with metal-black and carbon-supported catalysts, contain some microcracks initially; the area covered by these cracks increases both in the anode and cathode after 100-hours of DMFC test. X-ray tomography shows an increase in the crack area in both anode and cathode that correlates with methanol feed concentration and methanol crossover. The MEAs with carbon-supported catalysts and thicker membrane are more resistant to the formation of micro-cracks compared to those with metal-black catalysts and thinner membrane, respectively. The impact of the micro-crack formation on cell performance and durability is limited over the 100-hour DMFC operation, with the longterm impact remaining unknown.
\end{abstract}

Keywords: Direct methanol fuel cell, Performance degradation, Micro-cracks, X-ray tomography, Long-term stability 


\section{Introduction}

Direct methanol fuel cells (DMFCs) are a promising technology as a power source for portable and uninterruptible power supply applications, offering the advantage of a liquid fuel with high energy density and an ease of fuel storage and transportation. In the last decade, DMFC research has focused predominantly on developing materials and operating strategies to improve performance of membrane-electrode assemblies (MEAs) $[1,2]$. Despite the recent progress, several inherent problems still hinder the wide spread of DMFC technology. One of the most critical issues is performance degradation in longterm operation, which prevents present-day DMFCs from achieving performance stability for thousands of hours that, together with meeting cost targets, is required of a majority of portable power systems [3].

Over the past years, significant research efforts have been devoted to DMFC performance degradation during long-term operation [4]. A PtRu black/Nafion ${ }^{\circledR} 117 / \mathrm{Pt}$ black (anode/membrane/cathode) MEA after a DMFC life test exceeding $1000 \mathrm{~h}$ was examined by Cheng et al. [5]. The results revealed fast performance degradation during the first 200 hours, which slowed down between 200 and 704 hours, only to accelerate after 1002 hours of the test. Eickes et al. reported on DMFC performance loss due to the oxidation of a platinum cathode catalyst during continuous DMFC operation. This performance loss could be fully recovered by bringing the cathode potential down to a value corresponding to complete reduction of the surface $\mathrm{Pt}$ oxide [6]. Piela et al. reported that cathode contamination by $\mathrm{Ru}$ crossover inhibits oxygen reduction kinetics at the cathode resulting in up to $200 \mathrm{mV}$ performance loss during DMFC operation [7]. Recently, Bresciani et al. [8] proposed a strategy to mitigate degradation effects. Steadystate DMFC operation was interrupted periodically by refresh cycles involving open- 
circuit operation and cathode air interruption, which resulted in the reduction of permanent degradation (unrecoverable loss) by $28 \%$ as well as lower temporary degradation (recoverable loss) [8].

Catalyst loss and particle agglomeration have been identified as one of the main attributes of the DMFC performance loss. A $30 \%$ performance loss, attributed to the catalyst agglomeration, together with electrode delamination in the MEA, was reported by Liu et al. [9] after a 75-hour DMFC life test at a current density of $100 \mathrm{~mA} \mathrm{~cm}^{-2}$ using a PtRu/C/Nafion ${ }^{\circledR} 115 / \mathrm{Pt} / \mathrm{C}$ MEA. X-ray diffraction (XRD) and transmission electron microscopy (TEM) attest to an increase in the catalyst particle size in both the anode and cathode after a 500-hour test, with faster particle growth at the cathode in a $\mathrm{PtRu} / \mathrm{C} / \mathrm{Nafion}{ }^{\circledR} 115 / \mathrm{Pt} / \mathrm{C}$ MEA [10]. Similar results were reported by Kim [11], Sarma [12] and Park [13], with PtRu-black/Nafion ${ }^{\circledR}$ 115/Pt-black, PtRu-black/Nafion ${ }^{\circledR} 117 /$ Ptblack and PtRu-black/Nafion ${ }^{\circledR}$ 115/Pt-black MEAs, respectively. Changes in the alloying degree of Pt and $\mathrm{Ru}$ in anode catalysts caused by the Ru loss over time were observed by X-ray photoelectron spectroscopy (XPS), X-ray absorption spectroscopy (XAS), and energy dispersive X-ray spectroscopy (EDX) (all with metal black catalysts) and correlated with the DMFC performance loss $[12,14,15]$.

Other modes of MEA-component degradation have also been reported. Siroma et al. suggested that possible dissolution of recast $\mathrm{Nafion}^{\circledR}$ in mixtures of methanol and water can adversely impact the DMFC performance [16]. The degree of dissolution of recast Nafion ${ }^{\circledR}$ could be more than $30 \%$ at $80^{\circ} \mathrm{C}$ at a methanol concentration of $80 \%$. The performance decay caused by the decrease in the hydrophobicity of the gas diffusion layer (GDL) and subsequent cathode flooding was also observed with a PtRu/C/Nafion ${ }^{\circledR} 117 / \mathrm{Pt} / \mathrm{C}$ MEA [17]. Electrochemical impedance spectroscopy (EIS) was used to analyze DMFC performance decay after a 435-hour life test at a constant current 
density of $150 \mathrm{~mA} \mathrm{~cm}^{-2}$ with a PtRu-black/Nafion ${ }^{\circledR} 115 / \mathrm{Pt}$-black MEA. Contributions of various impedance components to the total cell impedance increase after the life test were as follows: ohmic resistance $-71 \%$; cathode reaction resistance - $24 \%$; anode reaction resistance - 5\% [18]. Electrode delamination can cause DMFC performance degradation as well. Our previous studies reported on membrane-electrode delamination which increased with the water uptake of the membrane and methanol feed concentration [1922]. The performance loss was accompanied with an increase in the cell resistance [2023].

Another possible DMFC degradation mode is electrode micro-cracking. While in general adversely impacting DMFC performance through a buckling deformation [24], pin-hole formation in the membrane [25], inhibiting multi-phase transport [26], and affecting the three-phase interface regions [27], the crack formation can also benefit the cell performance by facilitating access of reactants to the reaction site $[28,29]$. As a result, the overall effect of the catalyst layer cracks on the DMFC durability is not obvious. Furthermore, the fragility of catalyst layers makes it difficult for the postmortem analysis and often brings experimental uncertainties. In the present work, we depict micro-crack formation in DMFC MEAs using X-ray micro-tomography technique and discuss their impact on DMFC performance durability. Cracks in Nafion ${ }^{\circledR}$-based MEAs were systematically studied during DMFC operation for 100 hours at methanol feed concentrations of $0.5,1.0$, and $4.0 \mathrm{M}$, using metal-black and carbon-supported catalysts, catalyst-coated membranes and gas-diffusion electrodes, and membranes of different thickness (single- and three-layer membranes). The effects of cell operating conditions on the electrode structural change and performance degradation modes are discussed. 


\section{Experimental}

\subsection{MEA Preparation}

MEAs were fabricated using Nafion ${ }^{\circledR} 212$ membranes (DuPont) in acid form (singlelayer membranes by default, triple-layer membranes membrane where noted) and $\mathrm{Pt}$ based electro-catalysts (Johnson Matthey). Three types of electrodes were used in this study:

- MEA 1: Catalyst-coated membrane (CCM) with metal-black catalysts; $\mathrm{Pt}_{50} \mathrm{Ru}_{50}$ black (HiSPEC $^{\circledR}$ 6000) anode catalyst at $6.0 \mathrm{mg}_{\mathrm{P}_{\mathrm{t}}} / \mathrm{cm}^{2}$; Pt black (HiSPEC ${ }^{\circledR}$ 1000) cathode catalyst at $4.0 \mathrm{mg}_{\mathrm{P}} / \mathrm{cm}^{2}$.

- MEA 2: CCM with carbon-supported catalysts; PtRu/C (75\% metal loading, HiSPEC $\left.^{\circledR} 12100\right)$ anode catalyst at $2.7 \mathrm{mg}_{\mathrm{P} /} / \mathrm{cm}^{2} ; \mathrm{Pt} / \mathrm{C}\left(60 \%\right.$ metal loading, HiSPEC ${ }^{\circledR}$ 9100) cathode catalyst at $2.0 \mathrm{mg}_{\mathrm{Pt}} / \mathrm{cm}^{2}$.

- MEA 3: Gas-diffusion electrode (GDE) with carbon-supported catalysts (Johnson Matthey); PtRu/C (HiSPEC $\left.{ }^{\circledR} 12100\right)$ anode catalyst at $2.7 \mathrm{mg}_{\mathrm{Pl}} / \mathrm{cm}^{2} ; \mathrm{Pt} / \mathrm{C}\left(\mathrm{HiSPEC}^{\circledR}\right.$ 9100) at $2.0 \mathrm{mg}_{\mathrm{Pl}} / \mathrm{cm}^{2}$ cathode catalyst.

Catalyst inks for MEAs 1 and 2 were prepared by ultrasonically mixing catalyst powders with de-ionized water (Millipore ${ }^{\circledR}, 18 \mathrm{M} \Omega \mathrm{cm}$ ) and 5\% Nafion ${ }^{\circledR}$ suspension (Ion Power, Inc.) for 90 seconds. Catalyst inks were brush-painted onto the membrane at $75^{\circ} \mathrm{C}$ and dried for 30 min. MEA 3 was obtained by hot-pressing GDEs onto the membrane at $120^{\circ} \mathrm{C}$ and $45 \mathrm{~kg} \mathrm{~cm}^{-2}$ for $2 \mathrm{~min}$. The active cell area was $5 \mathrm{~cm}^{2}$.

\subsection{Fuel Cell Testing}

DMFC testing was carried out in a single $5 \mathrm{~cm}^{2}$ cell using a commercial fuel cell test station (Fuel Cell Technologies, Inc.). MEA was sandwiched between two graphite 
bipolar plates, each with a single-serpentine flow channel. The cell was operated at $80^{\circ} \mathrm{C}$. Methanol solution $(0.5,1.0$, or $4.0 \mathrm{M})$ was delivered to the anode at a flow rate of 1.8 $\mathrm{mL} / \mathrm{min}$ using a high-pressure liquid chromatography pump (Shimadzu LC-10AS). The cathode side was supplied with pre-humidified air at a high flow rate of $500 \mathrm{sccm}$ and ambient pressure. The temperature of cathode humidifier was set to $10^{\circ} \mathrm{C}$ higher than the cell temperature. While this is not practical conditions, this condition maintain the membrane humidification by pushing liquid water through cathode layer. High-frequency resistance (HFR) of the cell was measured using a sinusoidal voltage perturbation at 3333 $\mathrm{Hz}$ (chosen to minimize capacitance). Each cell was subjected to a two-hour break-in in a hydrogen/air fuel cell at $0.7 \mathrm{~V}$ using fully humidified gases at a backpressure of 1.4 bar. Long-term DMFC performance was investigated in 100-hour life tests at $0.45 \mathrm{~V}$. The cell HFR was monitored during life tests. The $\mathrm{CO}_{2}$ content in the cathode effluent was measured by a gas analyzer equipped with a calibrated non-dispersive infrared (NDIR) sensor (California Analytical Instruments, Inc.). The NDIR sensor was calibrated using certified $\mathrm{CO}_{2}$ gas cylinder and connected to cathode effluent before the $\mathrm{CO}_{2}$ measurement. Downstream from the fuel cell, water was completely removed from the gas stream by Drierite ${ }^{\circledR}$ water trap. Polarization curves were recorded before and immediately after each life test. In addition, the fuel cell performance was recorded after a performance recovery process which included cooling down and drying the cell. This post-recovery cell performance is denoted as recovered performance.

Unless noted otherwise, data reported below correspond to the following operating conditions of the fuel cell: temperature $80^{\circ} \mathrm{C}$, methanol flow rate $1.8 \mathrm{~mL} / \mathrm{min}$, air flow $500 \mathrm{sccm}$, fully humidified air. 


\subsection{X-Ray Microtomography}

After testing, the MEAs were removed from the fuel cell and dried. Micro X-ray computed tomography (microXCT) $[30,31]$ was employed to visualize changes in the internal morphology of the MEAs before and after life tests. Image sets of new and aged MEAs were recorded using a MicroXCT system (Xradia, Inc.). Each MEA sample was

placed between the X-ray source and the detector. Frequently, radiographs were taken at different rotation angles, from -90 to +90 degrees. Radiographs were reconstructed into three-dimensional tomographic images with a resolution of $\sim 2 \mu \mathrm{m}$ and a typical field of view of $1 \times 1 \mathrm{~mm}$.

\section{Results and Discussion}

\subsection{DMFC Performance Durability}

While DMFC MEAs using commercial membranes and electro-catalysts tend to exhibit stable performance under normal operating conditions, performance degradation is expected upon more extreme operation. Among non-customary conditions, operation on high methanol is of particular interest since it may be advantageous from a fuel cell system perspective (improved freeze tolerance, enhanced ability to respond to changing load, and increased limiting current densities [21]). Fig. 1 a-c shows DMFC performance and HFR of MEA 1 with methanol concentrations of $0.5 \mathrm{M}, 1.0 \mathrm{M}$, and $4.0 \mathrm{M}$, respectively. Performance degradation and HFR gain after 100 hour-life tests strongly depend on methanol concentration. While current density decreases over time for all methanol concentrations used, a certain fraction of the performance loss can be recovered by cell drying and subsequent re-humidifying after the life test. That fraction represents a recoverable performance loss [20]. The performance loss that cannot be recovered by drying and re-humidifying corresponds to unrecoverable, or permanent, performance loss. 
In general, unrecoverable performance loss can be attributed to several degradation mechanisms, such as degradation of the membrane and the membrane-electrode interface, which are manifested by the increase in the HFR after lift test. Unrecoverable performance loss may also come from ruthenium crossover, loss of active catalyst surface area, and changes in gas diffusion layer hydrophobicity [20]. In addition, we examine the possibility that the performance loss was affected by the structural change in the electrodes due to crack formation, as discussed in the following section. Recoverable and unrecoverable performance losses at $0.45 \mathrm{~V}$ after 100 -hour life tests at different methanol concentrations are summarized in Fig. 1d. The overall performance loss increases as methanol feed concentration increases, with its unrecoverable part increasing at "an expense" of the recoverable part. In other words, higher methanol feed concentration results in the acceleration of performance loss, most of which is unrecoverable.

The increased unrecoverable performance at higher methanol feed concentration seems to correlate with the HFR change. Fig. 2 shows HFR changes for MEA 1 during 100-hour life tests at different methanol feed concentration. The initial HFR value increases with methanol concentration, in agreement with earlier results $[32,33]$. The HFR changes during the life test depend on the concentration of methanol. For $0.5 \mathrm{M}$ methanol feed, HFR decreases during the first 60 hours and remains constant thereafter. The HFR decrease with $0.5 \mathrm{M}$ methanol can be explained by morphological relaxation of Nafion ${ }^{\circledR}$ membrane during the exposure of hot and humid conditions where hydrophilic domain structures are evolved resulting in an increase in proton conduction [34]. For 1.0 M methanol feed, HFR initially slightly decreases before assuming a slightly upward trend at longer times. For 4.0 M methanol concentration, HFR increases throughout the life test. The HFR increase and concurring rise at higher methanol concentrations are likely related to membrane-electrode delamination $[20,23]$. In our previous study, a 
dimensional mismatch between the electrodes and the polymer-electrolyte membrane due to the swelling/de-swelling was found to be the primary cause of the interfacial failure. Good correlation between cell HFR gain and membrane water uptake supported the hypothesis. While Nafion ${ }^{\circledR}$ membrane used in present study has relatively low water uptake (ca. $19 \mathrm{wt} \%$ ) and does not exhibit any interfacial delamination under $0.5 \mathrm{M}$ methanol feed, further membrane swelling at higher methanol concentrations may cause notable interfacial delamination. Fig. 3 shows the water uptake of $\mathrm{Nafion}^{\circledR}$ after a 100hour life test at $100{ }^{\circ} \mathrm{C}$ in pure water and in solutions with different methanol concentrations. The water uptake of Nafion ${ }^{\circledR}$ increased from 21 wt $\%$ for pure water to 40 $\mathrm{wt} \%$ for $4.0 \mathrm{M}$ methanol solution. Nafion ${ }^{\circledR}$ before drying at $80{ }^{\circ} \mathrm{C}$, i.e., immediately after life test, shows even greater water uptake due to the lack of thermal history but is subject to the same trend of increasing water uptake with high methanol concentration. This result is consistent with previous findings that excessive membrane swelling can cause delamination between the membrane and the electrodes and thus contribute to the unrecoverable performance loss [22]. At the same time, the loss of sulfonic groups in the Nafion ${ }^{\circledR}$ membrane can be ruled out as source of the HFR gain based on the FT-IR data

in Fig. S1, which show no change in the peak at $1064 \mathrm{~cm}^{-1}$ (symmetric vibration of sulfonated group in Nafion $^{\circledR}$ ) after 100-hour life test with 4.0 M methanol.

\subsection{Micro-Crack Formation}

\subsubsection{Effect of Methanol Concentration}

The MEA structure was examined by microXCT. Fig. 4a displays a typical threedimensional reconstructed tomography, identifying individual MEA components. Tomography results for MEA 1 reveal that both anode and cathode start almost crack- 
free and then both develop micro-cracks over time. To quantify this structural change, we employed an image-processing procedure shown in Fig. $\mathbf{4 b}$, where the processing steps are shown for anode of MEA 1 after life test at $4.0 \mathrm{M}$ methanol concentration. Thus, another distinctive change as a function of methanol feed concentration is crack formation in fuel cell electrodes. The cross-section images of the anode and cathode exhibited a significant crack development in the electrodes after 4.0 M methanol life test. Majority of cracks propagate through the entire thickness of the electrodes, i.e. from the outer electrode surface to the membrane-electrode interface (Fig. 4b, left). X-ray tomography images clearly show that the structural change of electrode occurred not only at electrode-membrane interface but also in the electrode itself. The crack formation is likely caused by the mechanical stress due to ionomer swelling and MEA compression in the cell, as well as by possible dissolution of the ionomer in the catalyst layers at higher methanol concentration. Fig. 5 shows electrode mid-sections before (Fig. 5a) and after a 100-hour life test (Fig. 5b-d) as a function of methanol feed concentration. The crack formation during DMFC operation is found to increase with increasing methanol concentration. Interestingly, the micro-cracks after the life test are observed not only at the anode but also at the cathode, suggesting that the presence of crossed-over methanol at the DMFC cathode may cause the crack formation. Fig. 6 displays the correlation between methanol concentration at the anode and cathode of each cell and the crack area fraction. The fraction of the cracked area at both the anode and cathode increases with methanol feed concentration. The cathode appears to be similarly sensitive to methanol feed concentration as the anode, which is surprising considered much higher methanol concentration at anode. The cathode crack formation is particularly high at $4.0 \mathrm{M}$ methanol feed concentration where the generated crack area of cathode exceeds that of the anode. The increased crack formation at higher methanol concentrations should be 
ascribed to an excessive volume change of Nafion. Methanol (and other alcohols) has a

greater affinity to the Nafion ionomer compared to water [35]. As a result, the volume

change of Nafion can be substantial after the exposure of concentrated methanol solution, as indicated in Fig. 3. The excessive volume expansion of the ionomeric phase can cause

the crack formation as well as the membrane-electrode delamination. Since there was no loss of sulfonic acid groups of Nafion ${ }^{\circledR}$ in the presence of $4.0 \mathrm{M}$ methanol (Fig. S1), it is believed that the micro-crack formation is not due to the chemical degradation or Nafion dissolution. Enhanced resistance of PtRu anodes to crack formation may be caused by the chemical and physicochemical properties of the alloy, including higher oxide content and slightly higher ionomer content. Since the crack formation is concomitant with membrane-electrode interfacial failure, it is difficult to separately assess the impact of crack formation on DMFC performance.

\subsubsection{Effect of Applied Voltage and Current Conditions}

In order to assess the effect of operating conditions on formation of micro-cracks, the DMFC was operated at the open cell voltage (OCV, non-constant), constant voltage of $0.45 \mathrm{~V}$, and constant current density of $0.60 \mathrm{~A} \mathrm{~cm}^{-2}$ at a methanol concentration of $1.0 \mathrm{M}$. Methanol crossover during the life test was estimated from $\mathrm{CO}_{2}$ measurement as a function of current density. As expected, methanol crossover drops with an increase in cell current density (decrease in cell voltage), reaching $0.35,0.33$ and $0.30 \mathrm{~A} \mathrm{~cm}^{-2}$ at OCV, $0.45 \mathrm{~V}\left(\sim 0.35 \mathrm{~A} \mathrm{~cm}^{-2}\right)$ and $0.6 \mathrm{~A} \mathrm{~cm}^{-2}$, respectively (Fig. S2). DMFC polarization plots before and after 100-hour life tests under these conditions are shown in Fig. 7. The performance loss is accelerated when cell is operated at a higher voltage. Slight HFR gain for the cell operated at $\mathrm{OCV}$ points to possible partial membrane-electrode delamination. No HFR changes were observed at the $0.45 \mathrm{~V}$ and $0.60 \mathrm{~A} \mathrm{~cm}^{-2}$ conditions, indicating no 
interfacial delamination formation needs to occur in order to adversely affect the fuel cell performance. Small delamination at OCV aside, the fractions of the cracked area are similar in all three cases, and are close to the case of $1.0 \mathrm{M}$ life test at $0.45 \mathrm{~V}$ from Fig. 6. Thus it seems that more substantial micro-crack crack development in the cathode will take place at sufficiently high methanol concentration. Cathode crack area increased about 3 times when the methanol concentation increased from 0.09 to $0.29 \mathrm{M}$ (Fig. 6, life tests with 1.0 and 4.0 M methanol feed concentration, respectively). Similar crack areas were measured at $1.0 \mathrm{M}$ for $\mathrm{OCV}$ and $0.45 \mathrm{~V}$ (life test), with OCV having higher methanol concentration of $0.10 \mathrm{M}$. An abrupt increase in crack development at the cathode occurred at the methanol concentration between 0.10 and $0.29 \mathrm{M}$.

\subsubsection{Metal-Black vs. Carbon-Supported Electrocatalysts}

Fig. 8a depicts the DMFC performance and HFR before and after a 100-hour life test recorded with MEA 2, 4.0 M methanol feed concentration and single Nafion ${ }^{\circledR} 212$ membrane. Compared to that of black catalysts (MEA 1, Fig. 1c), MEA 2 shows poor initial performance, attributed to lower total Pt loading relative to that in MEA $1, c a$. 10

vs. $4.7 \mathrm{mg}_{\mathrm{Pt}} / \mathrm{cm}^{2}$. However, MEA 2 shows much reduced performance loss after 100-hour life test $(\sim 15 \%$ at $0.35 \mathrm{~V})$ relative to MEA $1(\sim 55 \%$ at $0.35 \mathrm{~V})$. No HFR gain indicates that the membrane-electrode interface is more robust with carbon-supported catalysts, preventing delamination during the life test. X-ray tomography images and measured crack-area fractions at the anode and cathode before and after life tests are shown in Fig. 8c and Fig. 9. The crack area increase for anode and cathode during life test are 4.9 and $4.1 \%$, respectively, compared to 4.4 and $8.1 \%$ increase for electrodes using metalblack catalysts (Fig. 6). The decrease in the cell performance in spite of HFR remaining constant suggests that performance loss in this case may be related to the crack formation. 
This result indicates that the good durability of MEAs using carbon-supported catalyst was largely due to the improved interfacial compatibility while the electrode micro-crack formation had a marginal impact.

\subsubsection{Effect of Membrane Thickness (Single- vs. Three-Layer Membranes)}

The effect of membrane thickness on the DMFC performance and HFR during the life test was studied with the carbon-supported catalysts (MEA 2) using 4.0 M methanol and single-layer (Fig. 8a) and three-layer (Fig. 8b) Nafion ${ }^{\circledR} 212$ membranes. Cells with both single- and three-layer membranes reveal insignificant performance loss and HFR gain, indicating that MEAs utilizing carbon-supported catalysts do not suffer from membrane delamination during a 100-hour life test. The crack-area fractions before and after the life test as a function of membrane thickness are shown for the anode and cathode in Fig. 8c. The crack-area fractions are lower when a thicker membrane is used, especially for the cathode, indicating that reduced methanol crossover may lead to fewer cracks. However, the increase in the crack area does not seem to affect the fuel cell performance in this case, which is a surprising result given the fact that cracks caused by higher methanol concentrations (Section 3.2.1) could be correlated with the DMFC performance loss. The apparent inconsistency in the relationship between crack formation and performance loss can be explained by differences in electrodes utilizing Pt-black and carbon-supported Pt electrocatalysts. In the case of Pt-black cathode, the micro-crack presence before the life test was minimal, $c a .0 .2 \%$ crack-area fraction, but became quite significant, $c a .8 .3 \%$, following a 100-hour life test in 4.0 M methanol. In contrast to Pt-back cathode, the Pt/Cbased cathode the micro-crack presence at beginning of life test under the same conditions is already significant, $c a .5 .8 \%$, increasing to $c a .10 .0 \%$ at end of life test (cf.

Fig. 5 and Fig. 9). This suggests that the structural change of Pt-black electrode during 
the life is much more substantial than that of the Pt/C-based electrode, by a factor of approximately 40 and 2 for Pt black and Pt/C, respectively (as measured by an increase in the micro-crack surface area). As stated before, clearly observable performance loss requires certain level of micro-crack formation, which has not been reached in the case cell operated with the $\mathrm{Pt} / \mathrm{C}$ cathode.

\subsubsection{Micro-crack Formation in GDE-Based MEA}

Based on the above experiments, MEAs with carbon-supported catalysts and thicker membrane afford better electrode durability and interfacial adhesion than MEAs with black catalysts and thinner membrane. In this section, we examine the crack formation in gas diffusion electrodes used in MEA 3. The DMFC performance and HFR before and after $100 \mathrm{~h}$ life test measured with MEA 3 are shown in Fig. 10a. MEA 3 exhibits slightly higher OCV and improved DMFC performance than MEA 2, likely due to GDE being better than the hand-painted MEA 2. After a $100 \mathrm{~h}$ life test on $4.0 \mathrm{M}$ methanol, MEA 3 exhibits good durability and no significant performance loss. Slight HFR increase, from 0.19 to $0.21 \Omega \mathrm{cm}^{2}$, indicates a possible deterioration of interfacial contact between the GDE (GDEs) and the membrane. X-ray tomography images and measured crack-area fractions at the anode and cathode during the MEA 3 life tests are shown in Fig. 10b-e and Fig. 10f, respectively. Compared to MEA 2, which develops cracks only, the open GDE area is comprised of both cracks and round holes, which is likely benefits mass transport and improves higher-current performance. Total anode and cathode crack fractions are 15.4 and $11.4 \%$ for GDE vs. $6.4 / 5.8 \%$ for CCM. It appears that mechanical strength of the GDL support in GDEs enables structural integrity of the electrodes with more open area. After a $100 \mathrm{~h}$ life test, both electrodes of MEA 3 reveal some additional cracks (4.4 and 3.7\%, for the anode and the cathode, respectively) and retaining the open 
structure comprised of round holes and cracks. The formation of additional cracks during the $100 \mathrm{~h}$ life test does not cause a significant performance loss. This result is consistent with those for CCM-based MEAs (MEA 2) that crack formation is an electrode-aging process that has a minimal impact on DMFC performance and durability over relatively 100-hour testing.

\section{Summary}

In this work, the micro-crack formation in Nafion ${ }^{\circledR}$-based MEAs was studied by subjecting MEAs to $100 \mathrm{~h}$ extended DMFC tests using three feed concentrations of methanol, metal-black and carbon-supported catalysts, membranes with two different thicknesses, and differently processed MEAs. The subsequent X-ray tomography analysis was conducted to characterize micro-structural changes in MEAs during the life tests.

The results indicate that micro-crack formation in DMFC electrodes should be considered as one of the aging processes possibly preceding performance degradation. The crack formation in MEAs with metal-black catalysts occurs concomitantly with membrane-electrode interfacial failure throughout the electrode thickness. Study using carbon-supported electrocatalysts, thicker membranes and commercial electrodes lead to the following conclusions: (i) all DMFC-type electrodes, whether prepared from using unsupported metal blacks or carbon-supported catalysts show some initial micro-cracks, the area of which increases in both the anode and cathode during a $100 \mathrm{~h}$ DMFC test; (ii) higher methanol concentrations, thinner membrane, and the use metal-black catalysts generate more and larger cracks; (iii) carbon-supported catalysts shows better stability than metal-black catalysts and improved resistance to crack formation; (iv) for MEAs utilizing state-of-the-art carbon-supported catalysts, crack formation has little effect, if any on performance and durability in the first $100 \mathrm{~h}$ of DMFC operation. However 
possible effects of crack-formation on fuel cell performance and stability can be critical

as we reported the stability of Nafion membrane strongly depends on electrode

uniformity, particularly with micro-crack formation [36].

\section{Acknowledgments}

Financial support from the DOE-EERE Fuel Cell Technologies Program is gratefully acknowledged. We thank Johnson Matthey Fuel Cells for supplying electrocatalysts and GDE materials. Los Alamos National Laboratory is operated by Los Alamos National Security LLC for the U.S. Department of Energy's National Nuclear Security Administration under Contract DE-AC52-06NA25396.

\section{References}

[1] X. Zhao, M. Yin, L. Ma, L. Liang, C. P. Liu, J. H. Liao, T. H. Lu, W. Xing, Energ Environ Sci 4 (2011) 2736-2753.

[2] S. C. Thomas, X. M. Ren, S. Gottesfeld, P. Zelenay, Electrochim Acta 47 (2002) 3741-3748.

[3] S. Y. Ahn, S. J. Shin, H. Y. Ha, S. A. Hong, Y. C. Lee, T. W. Lim, I. H. Oh, J Power Sources 106 (2002) 295-303.

[4] Q. Li, D. Spernjak, P. Zelenay, Y. S. Kim, ECS Trans. 50 (2013) 2199-2205.

[5] X. Cheng, C. Peng, M. D. You, L. Liu, Y. Zhang, Q. B. Fan, Electrochim Acta 51 (2006) 4620-4625.

[6] C. Eickes, P. Piela, J. Davey, P. Zelenay, J Electrochem Soc 153 (2006) A171-A178.

[7] P. Piela, C. Eickes, E. Brosha, F. Garzon, P. Zelenay, J Electrochem Soc 151 (2004) A2053-A2059. 
[8] F. Bresciani, A. Casalegno, J. L. Bonde, M. Odgaard, R. Marchesi, Int J Energ Res 38 (2014) 117-124.

[9] J. G. Liu, Z. H. Zhou, X. X. Zhao, Q. Xin, G. Q. Sun, B. L. Yi, Phys Chem Chem Phys 6 (2004) 134-137.

[10] W. M. Chen, G. Q. Sun, J. S. Guo, X. S. Zhao, S. Y. Yan, J. Tian, S. H. Tang, Z. H. Zhou, Q. Xin, Electrochim Acta 51 (2006) 2391-2399.

[11] H. Kim, S. J. Shin, Y. G. Park, J. Song, H. T. Kim, J Power Sources 160 (2006) 440445.

[12] L. S. Sarma, C. H. Chen, G. R. Wang, K. L. Hsueh, C. P. Huang, H. S. Sheu, D. G. Liu, J. F. Lee, B. J. Hwang, J Power Sources 167 (2007) 358-365.

[13] J. Y. Park, M. A. Scibioh, S. K. Kim, H. J. Kim, I. H. Oh, T. G. Lee, H. Y. Ha, Int J Hydrogen Energ 34 (2009) 2043-2051.

[14] Z. B. Wang, H. Rivera, X. P. Wang, H. X. Zhang, P. M. Feng, E. A. Lewis, E. S. Smotkin, J Power Sources 177 (2008) 386-392.

[15] Z. B. Wang, X. P. Wang, P. J. Zuo, B. Q. Yang, G. P. Yin, X. P. Feng, J Power Sources 181 (2008) 93-100.

[16] Z. Siroma, N. Fujiwara, T. Ioroi, S. Yamazaki, K. Yasuda, Y. Miyazaki, J Power Sources 126 (2004) 41-45.

[17] H. C. Cha, C. Y. Chen, J. Y. Shiu, J Power Sources 192 (2009) 451-456.

[18] M. K. Jeon, J. Y. Won, K. S. Oh, K. R. Lee, S. I. Woo, Electrochim Acta 53 (2007) 447-452.

[19] B. S. Pivovar, Y. S. Kim, J Electrochem Soc 154 (2007) B739-B744.

[20] Y. S. Kim, M. Einsla, J. E. McGrath, B. S. Pivovar, J Electrochem Soc 157 (2010) B1602-B1607.

[21] Y. S. Kim, B. S. Pivovar, J Electrochem Soc 157 (2010) B1608-B1615. 
[22] Y. S. Kim, B. S. Pivovar, J Electrochem Soc 157 (2010) B1616-B1623.

[23] Z. B. Wei, S. L. Wang, B. L. Yi, J. G. Liu, L. K. Chen, W. J. Zhou, W. Z. Li, Q. Xin, J Power Sources 106 (2002) 364-369.

[24] T. Uchiyama, H. Kumei, T. Yoshida, J Power Sources 238 (2013) 403-412.

[25] M. Pestrak, Y. Q. Li, S. W. Case, D. A. Dillard, M. W. Ellis, Y. H. Lai, C. S. Gittleman, J Fuel Cell Sci Tech 7 (2010)

[26] F. E. Hizir, S. O. Ural, E. C. Kumbur, M. M. Mench, J Power Sources 195 (2010) 3463-3471.

[27] Y. S. Kim, C. F. Welch, N. H. Mack, R. Hjelm, E. B. Orler, M. Hawley, K. S. Lee, S. D. Yim, C. M. Johnston, Phys Chem Chem Phys 2014) DOI: 10.1039/C1034CP00496E.

[28] N. Karst, V. Faucheux, A. Martinent, P. Bouillon, J. P. Simonato, J Power Sources 195 (2010) 5228-5234.

[29] M. P. Manahan, S. Kim, E. C. Kumbur, M. M. Mench, ECS Trans. 25 (2009) 17451754.

[30] F. Garzon, S. H. Lau, J. Davey, R. Borup, ECS Trans. 11 (2007) 1139.

[31] D. Spernjak, J. Fairweather, R. Mukundan, T. Rockward, R. L. Borup, J Power Sources 214 (2012) 386-398.

[32] L. Chaabane, L. Dammak, V. V. Nikonenko, G. Bulvestre, B. Auclair, J Membrane Sci 298 (2007) 126-135.

[33] L. Chaabane, G. Bulvestre, C. Innocent, G. Pourcelly, B. Auclair, Eur Polym J 42 (2006) 1403-1416.

[34] Y. S. Kim, L. M. Dong, M. A. Hickner, B. S. Pivovar, J. E. McGrath, Polymer 44 (2003) 5729-5736. 
[35] C. Welch, A. Labouriau, R. Hjelm, B. Orler, C. Johnston, Y. S. Kim, ACS Macro Letters 1 (2012) 1403-1407.

[36] B. Choi, D. A. Langlois, N. Mack, C. M. Johnston, Y. S. Kim, J Electrochem Soc in print (2014). 


\section{Figure Captions}

Figure 1. DMFC performance with MEA 1 before and after $100 \mathrm{~h}$ life test at $0.45 \mathrm{~V}$ with single Nafion ${ }^{\circledR} 212$ membrane at different methanol concentrations: (a) 0.5 M, (b) $1.0 \mathrm{M}$, and (c) 4.0 M. (d) Comparison of recoverable and unrecoverable performance losses at $0.45 \mathrm{~V}$ after the life tests.

Figure 2. Time dependence of high-frequency resistance (HFR) at different methanol feed concentrations during 100-hour DMFC life tests with MEA 1 (corresponding DMFC polarization data before and after life tests are shown in Fig. 1).

Figure 3. Water uptake of Nafion ${ }^{\circledR} 212$ membrane (acid form) before and after life test for $100 \mathrm{~h}$ at $100{ }^{\circ} \mathrm{C}$ in pure water (zero point in the graph) and in different methanol concentrations. The water uptake measured immediately after the life test (black bars) and after subsequent drying at $80^{\circ} \mathrm{C}$ for $2 \mathrm{~h}$ (grey bars).

Figure 4. (a) Typical reconstructed three-dimensional microXCT of an MEA, showing the membrane, electrodes, and GDLs (carbon cloth shown). (b) Image processing procedure to calculate the crack coverage area in the electrode. Cross sectional images show $1 \times 1 \mathrm{~mm}$ area.

Figure 5. Effect of methanol concentration on crack formation in MEA 1 electrodes with single Nafion ${ }^{\circledR} 212$ membrane during a 100-hour life test. X-ray tomography crosssectional images of the anode and the cathode $(1 \times 1 \mathrm{~mm}$ areas shown): (a) before life test; and after life test with (b) $0.5 \mathrm{M}$, (c) $1.0 \mathrm{M}$, and (d) 4.0 M methanol. Corresponding fuel cell test results shown in Figures 1 and 2. 
Figure 6. Influence of methanol concentration on crack fraction in the anode and cathode of MEA 1 before and after $100 \mathrm{~h}$ life test (corresponding fuel cell test data shown in Figures 1 and 2)

Figure 7. DMFC polarization plots for MEA 1 with single-layer Nafion ${ }^{\circledR} 212$ membrane using $1.0 \mathrm{M}$ methanol before and after 100 -hour test (recovered) at (a) $0.60 \mathrm{~A} \mathrm{~cm}^{-2}$, (b) $0.45 \mathrm{~V}$, and (c) OCV.

Figure 8. (a) DMFC performance and HFR for MEA 2 before and after $100 \mathrm{~h}$ life test (recovered) with $4.0 \mathrm{M}$ methanol and (a) single and (b) three-layer Nafion ${ }^{\circledR} 212$ membrane. (c) Anode and cathode crack area comparison for fresh vs. tested electrode with single- and three-layer membranes.

Figure 9. X-ray tomography images of MEA 2 cross-sections before and after $100 \mathrm{~h}$ life test with 4.0 M methanol and single Nafion ${ }^{\circledR} 212$ membrane: (a) anode before life test; (b) cathode before life test; (c) anode after life test; (d) cathode after life test.

Figure 10. (a) DMFC performance and HFR of MEA 3 before and after $100 \mathrm{~h}$ lift test with 4.0 M methanol and three-layer $\mathrm{Nafion}^{\circledR} 212$ membrane (recovered); cell temperature $75^{\circ} \mathrm{C}$. (b-e) X-ray tomography images electrode cross-sections: (b) anode before life test; (c) cathode before life test; (d) anode after life test; (e) cathode after life test; (f) crack area comparison for MEA 3 with three-layer membrane for fresh $v s$. tested electrode. 

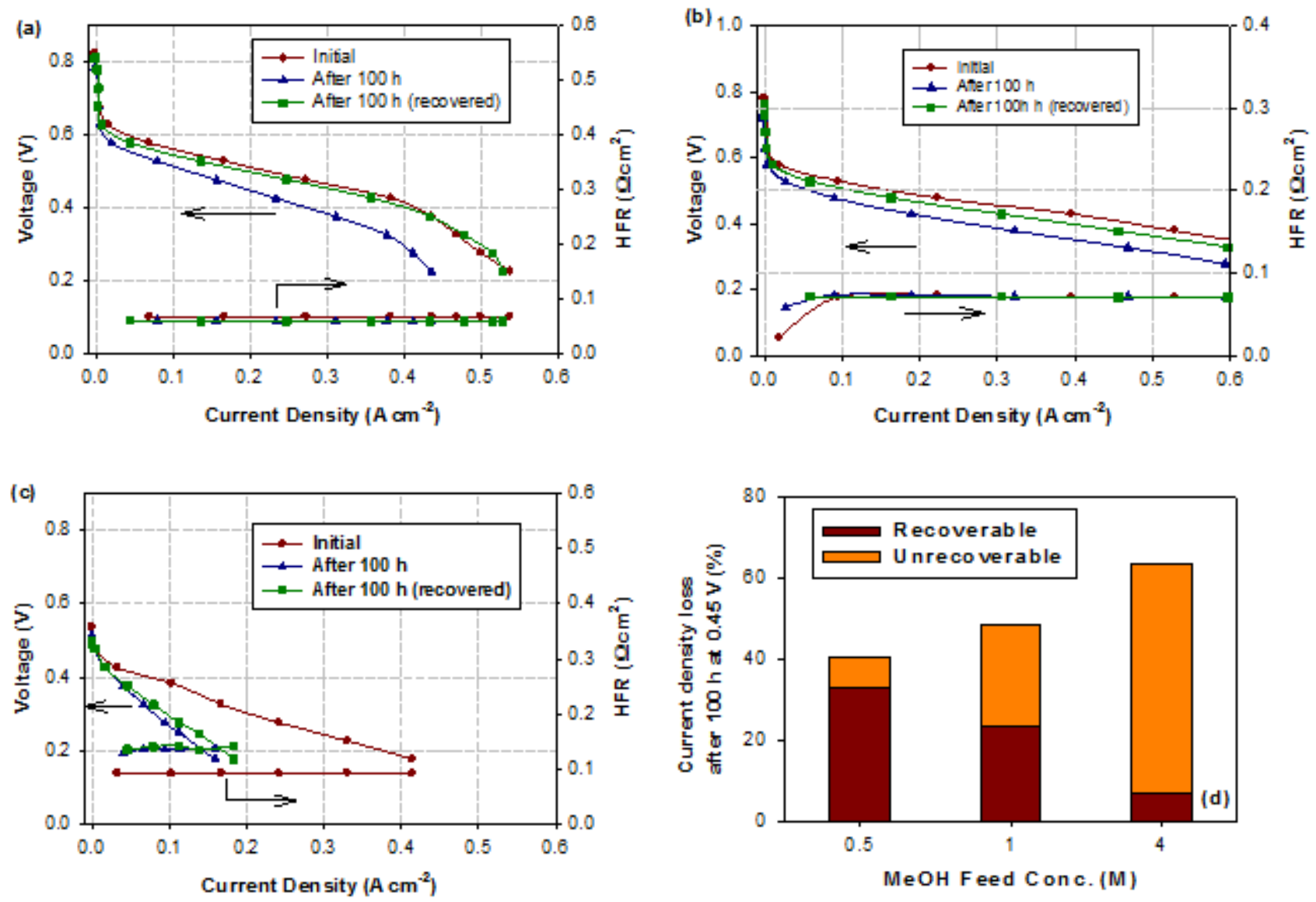

Figure 1 


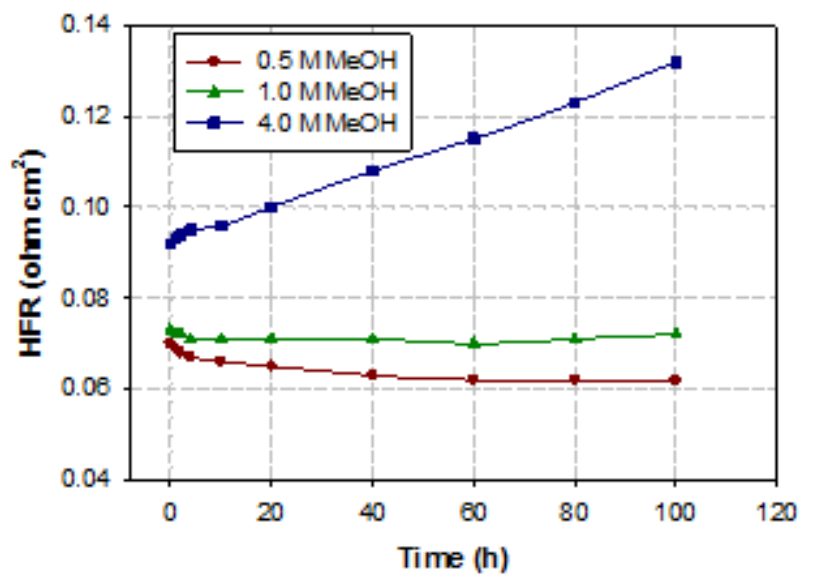

Figure 2 


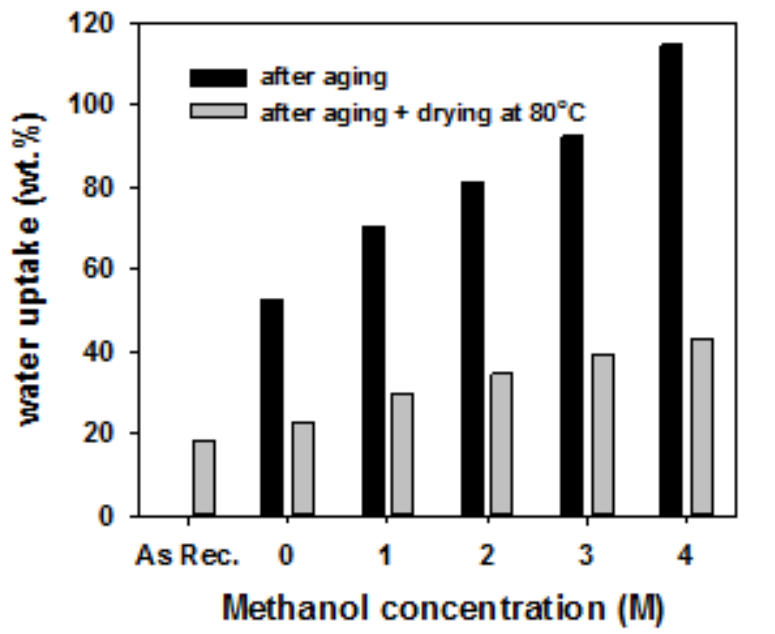

Figure 3 
(a)

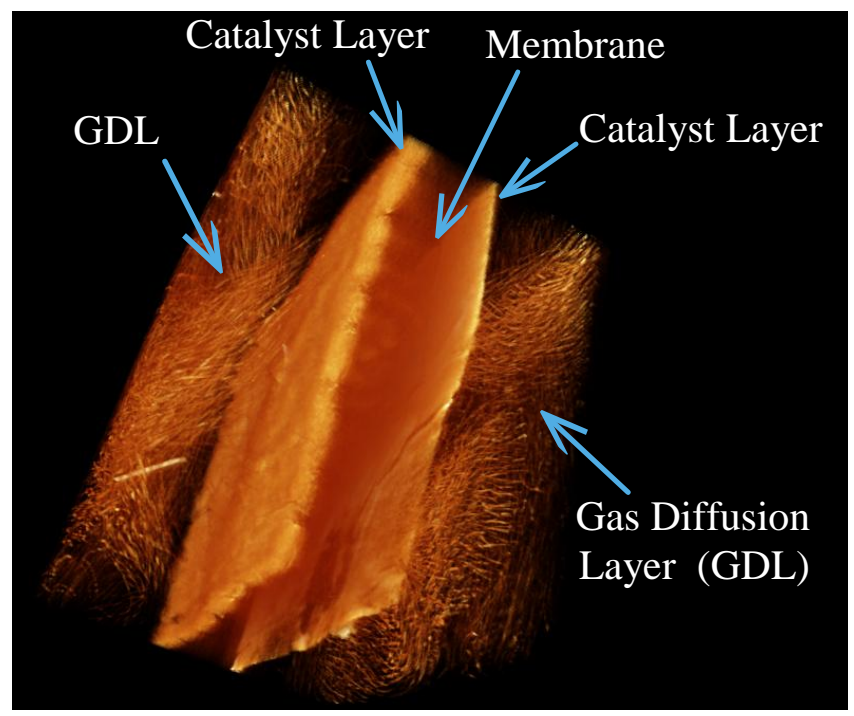

(b)

MEA cross-section from 3D tomography

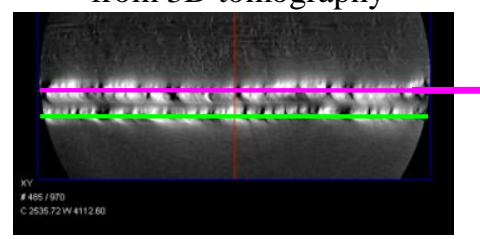

Cracks propagate through the thickness of the catalyst layer
Set the grayscale Anode cross-section

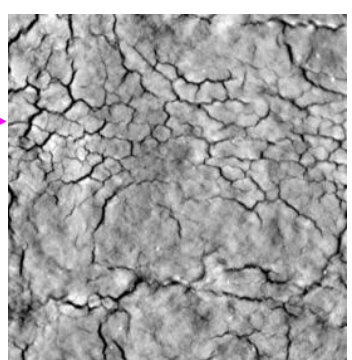

hreshold for the cracks

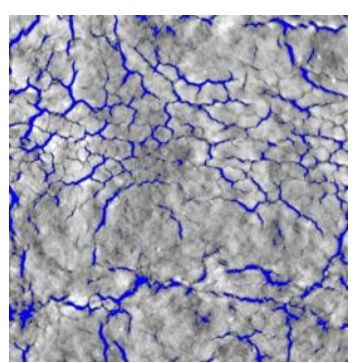

Calculate crack area fraction $(\%)$

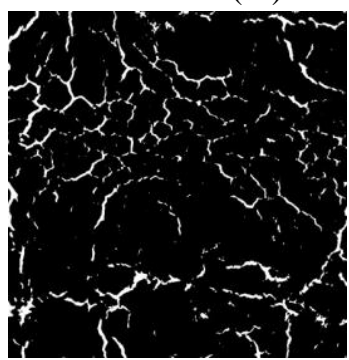

Figure 4 


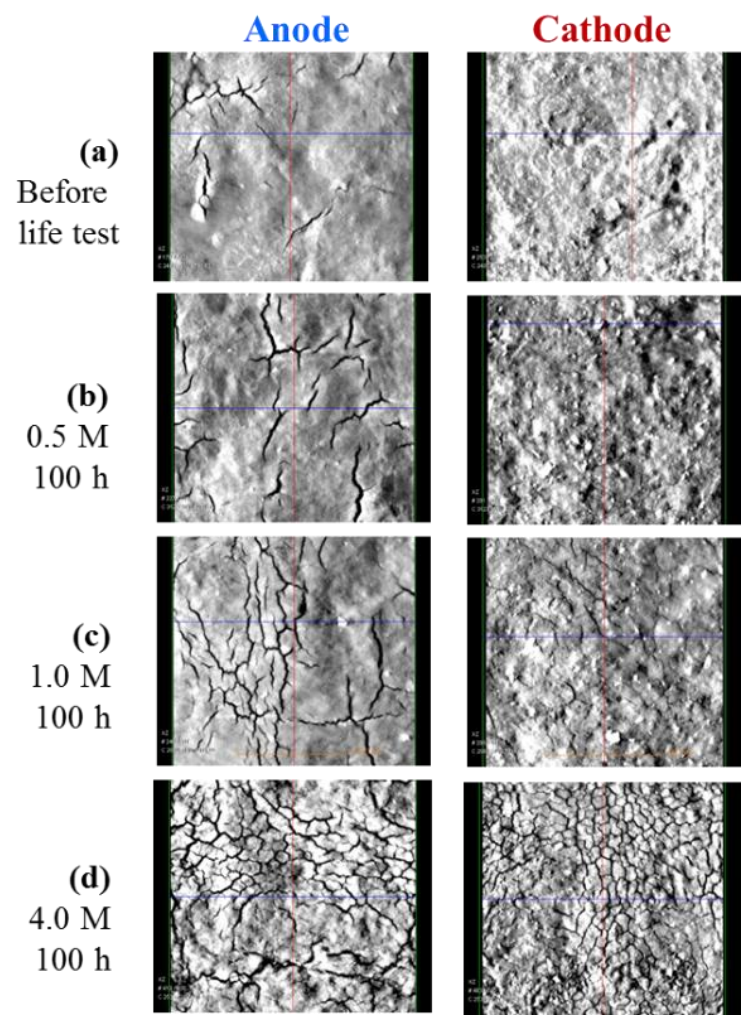

Figure 5 


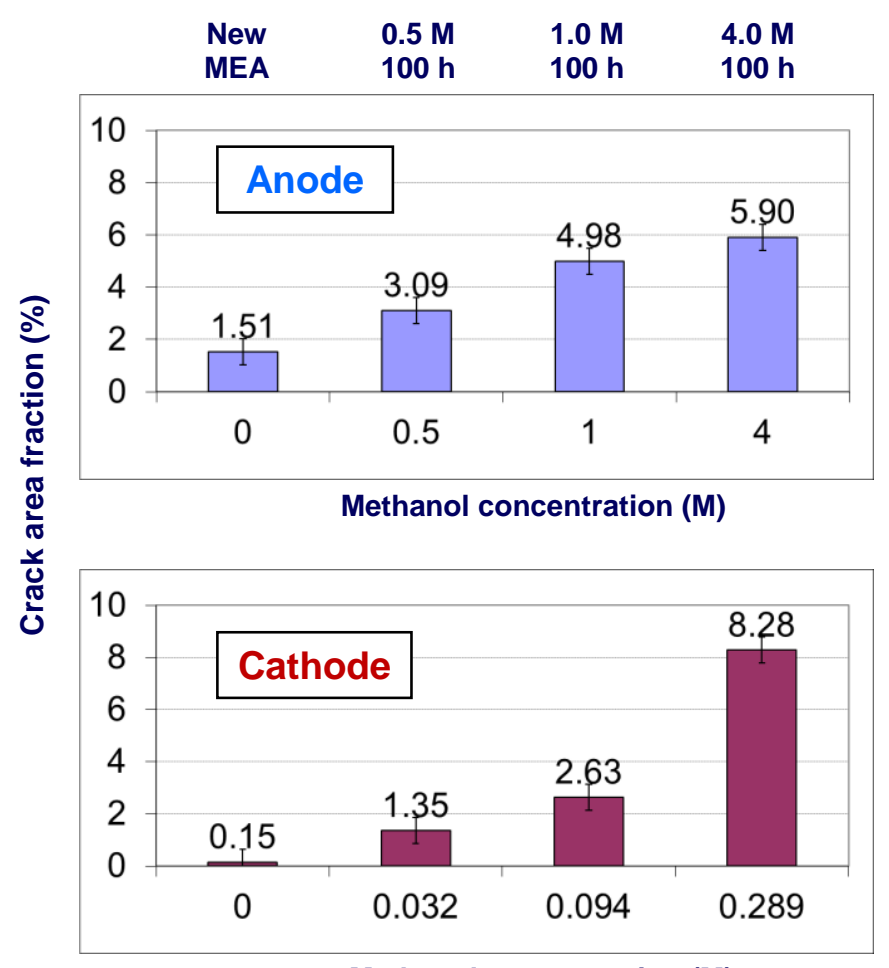

Figure 6 

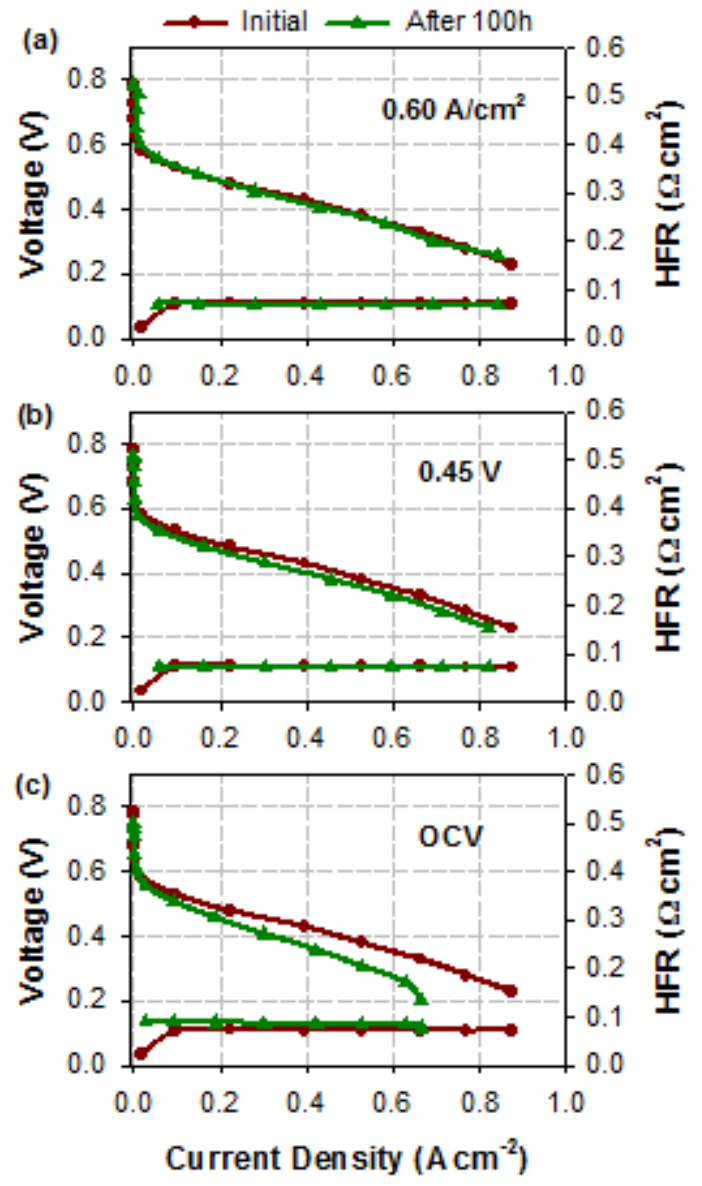

Figure 7 


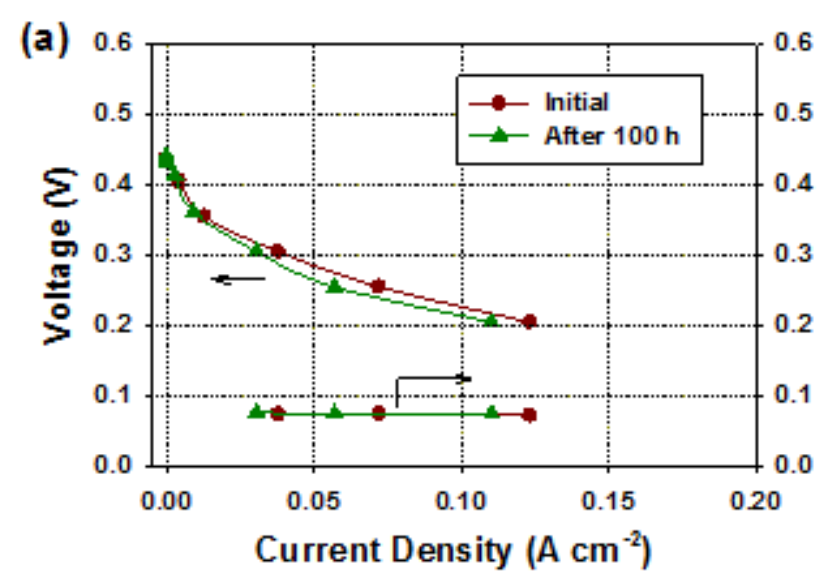

(c)

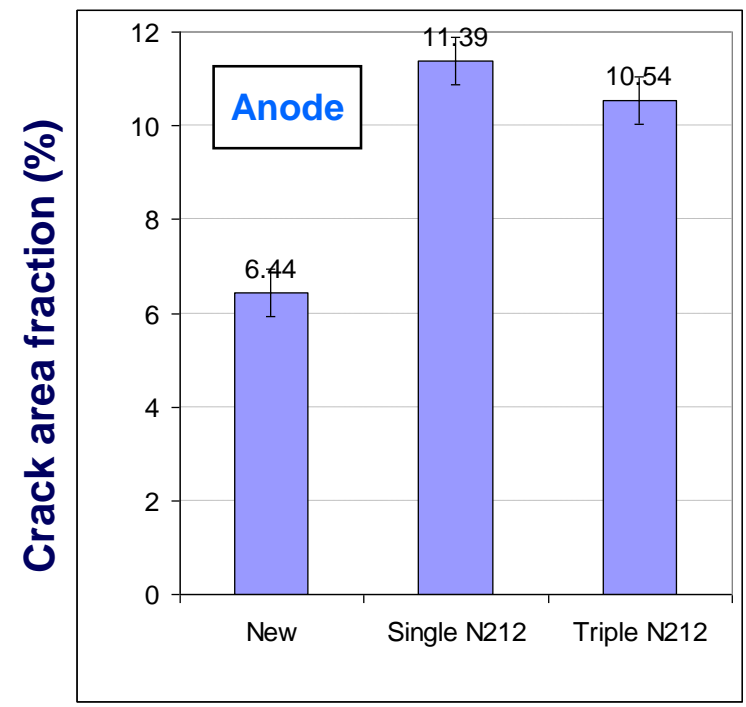

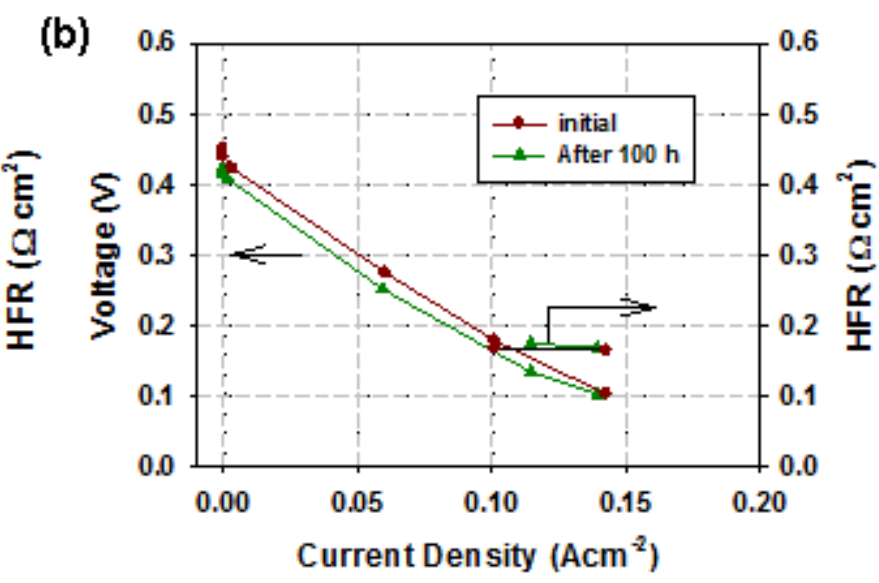

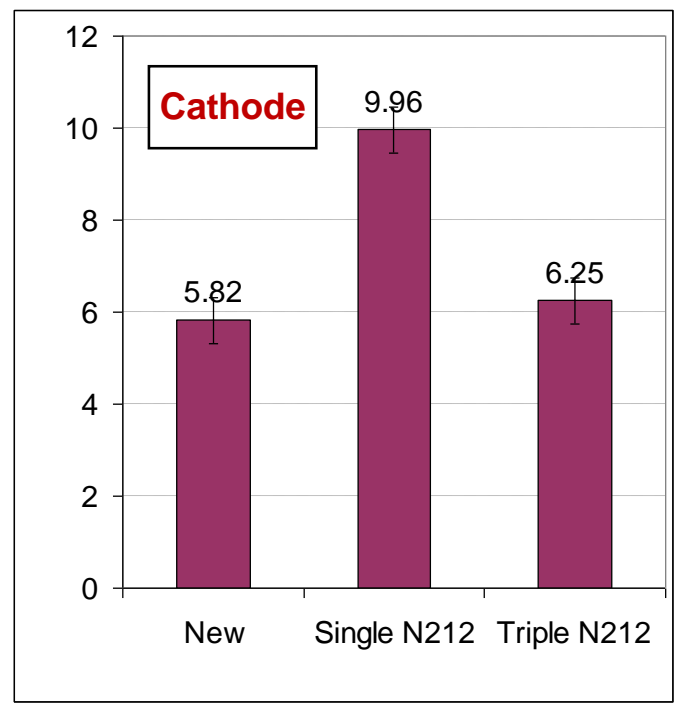

Figure 8 


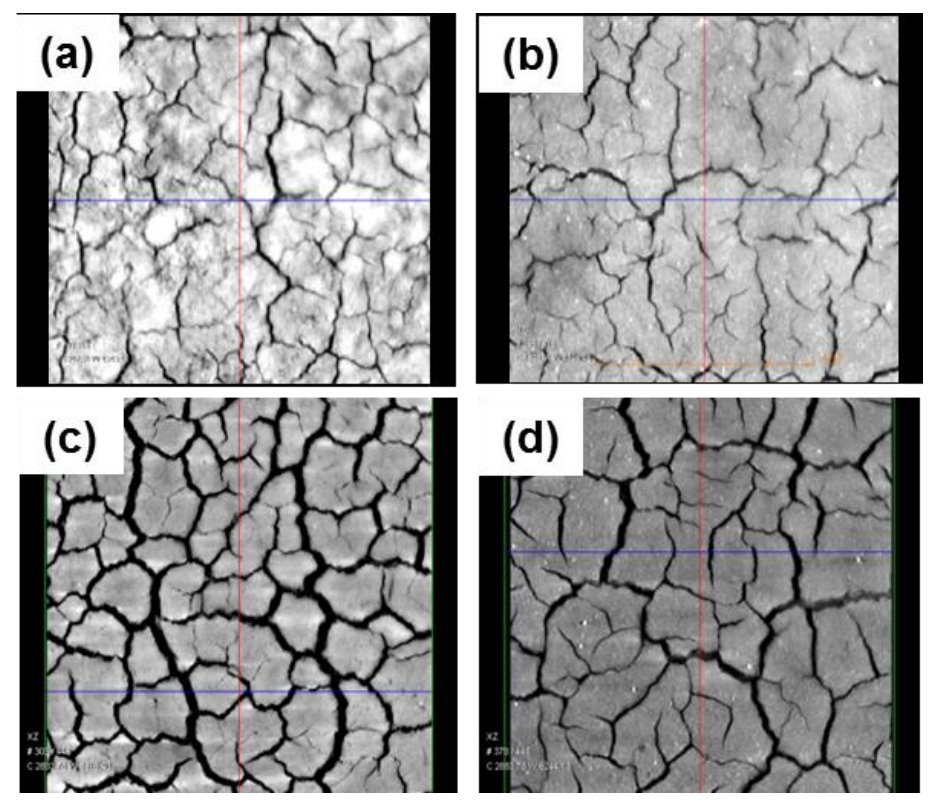

Figure 9 

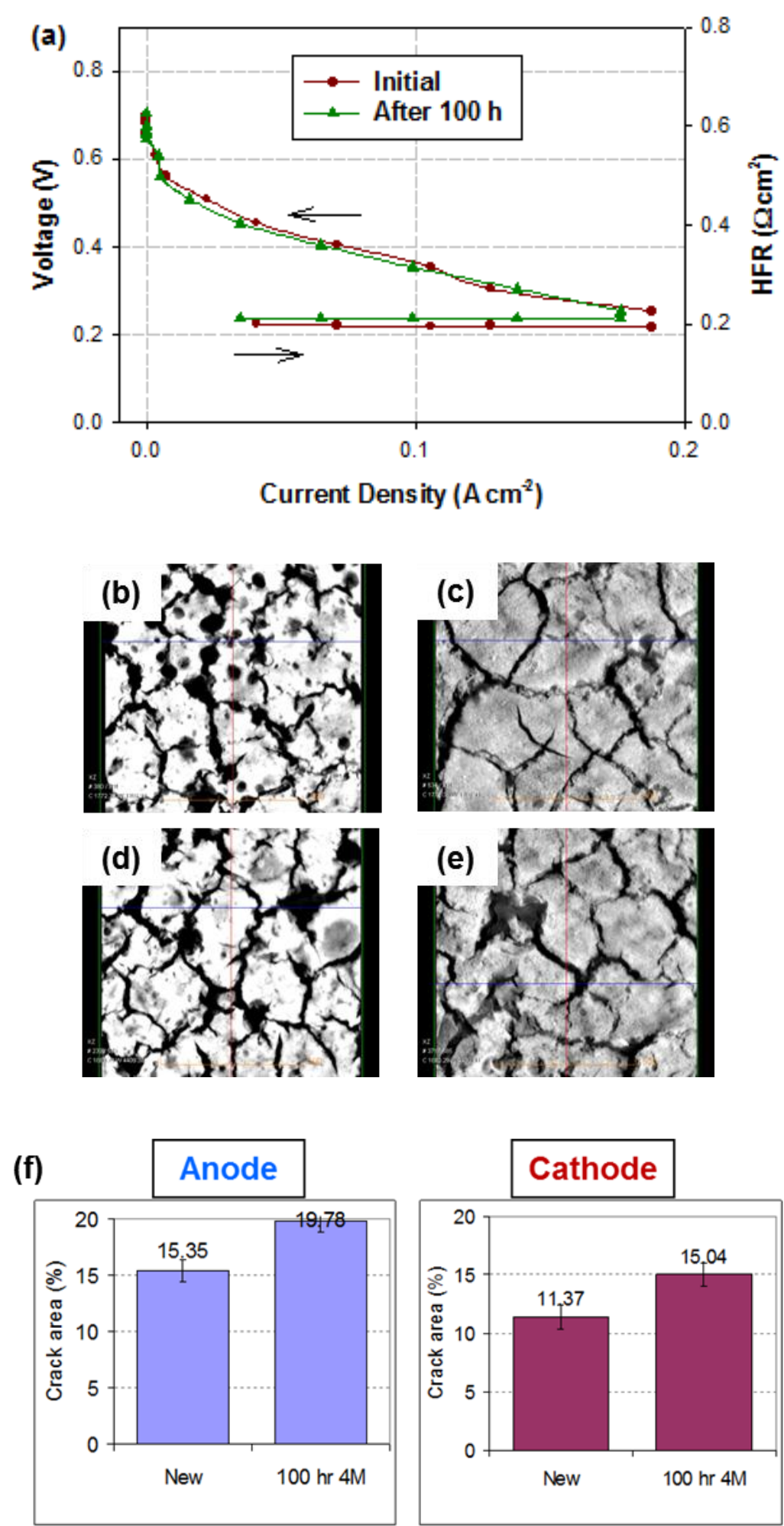

Figure 10 